\title{
Genetic differences in root mass of Lolium perenne varieties under field conditions
}

\author{
Joachim Deru • Henk Schilder • \\ Jan Rinze van der Schoot • Nick van Eekeren
}

Received: 17 December 2013/Accepted: 21 April 2014

(C) Springer Science+Business Media Dordrecht 2014

\begin{abstract}
Although grasses have dense rooting systems, nutrient uptake and productivity can be increased, and $\mathrm{N}$-leaching reduced, if rooting is further improved. The variation in root mass of 16 varieties of Lolium perenne was studied under field conditions in two experiments on sandy soil in The Netherlands. The chosen varieties differed in genetic and aboveground characteristics such as ploidy, productivity and grass cover. Root dry matter (RDM) was measured in the $0-8,8-16$ and 16-24 cm soil layers. In summary, we found that RDM of perennial ryegrass differed significantly between varieties under field conditions. These differences were not linked to grass yield, which indicates that it is possible to select perennial ryegrass varieties that combine high aboveground productivity with high RDM. In the first experiment, which was managed by cutting, diploid varieties had higher RDM than tetraploid varieties. Grand mean RDM in the second experiment, which was managed by cutting as well as grazing, was lower than in the first experiment.
\end{abstract}

J. Deru $(\square) \cdot$ N. van Eekeren

Louis Bolk Institute, 3972 LA Driebergen,

The Netherlands

e-mail: j.deru@louisbolk.nl

H. Schilder

Wageningen UR Livestock Research, 8200 AB Lelystad,

The Netherlands

J. R. van der Schoot

Wageningen UR Applied Plant Research,

8200 AK Lelystad, The Netherlands
In this experiment, total RDM was not influenced by ploidy but by grass cover type: high grass cover types had higher RDM. Differences in management between the two experiments possibly explain the differences in RDM and in the influence of chosen characteristics on RDM. Considering challenges in the areas of climate change, water availability, pollution and soil degradation, grass varieties with improved root systems could significantly contribute to a more efficient use of nutrients and water, erosion control, soil improvement and carbon sequestration.

Keywords Grass - Lolium perenne ·

Root length $\cdot$ Root mass $\cdot$ Varieties

\section{Introduction}

Roots play an important role in matching crop productivity goals with environmental goals (Atkinson et al. 2005; Lynch 2007). Although grasses already have dense rooting systems compared to arable crops (Jackson et al. 1996), there is still room for improvement: with increased rooting, nutrient uptake and productivity can be further improved, and environmental pollution such as nitrogen $(\mathrm{N})$ leaching further reduced (Crush et al. 2009; Moir et al. 2012; Snow and White 2013). In addition to nutrient uptake, increased rooting will also improve water uptake 
(Garwood and Sinclair 1979; White and Snow 2012), supply of organic matter to the soil (Abberton et al. 2008), building of soil structure (Bronick and Lal 2005), competition with weeds (Baan Hofman and Ennik 1980; Ennik and Baan Hofman 1983) and erosion control for hills and dikes (Sprangers 1999).

Nutrient uptake from the soil by a root system is a combination of root uptake activity and root morphology (Robinson et al. 1991; Dunbabin et al. 2003). Root morphology like root depth and density are determining factors in the uptake of nitrogen and phosphate, despite the great differences in mobility and availability of both nutrients. For $\mathrm{N}$ uptake, both root depth and root growth are crucial in conditions where $\mathrm{N}$ leaching is likely to occur (Bowman et al. 1998; Crush et al. 2007). Root density has also been correlated to better $\mathrm{N}$ uptake, particularly in mixed-species grasslands where interspecific competition plays a role (Hodge et al. 1999), and in conditions favourable to $\mathrm{N}$ leaching (Andrews and Newman 1970). For phosphate uptake, root and root-hair density are the most important factors: the root-soil interface for P uptake is greater in denser root systems with more root hairs (Forde and Lorenzo 2001; Lynch 2007). Furthermore, actively growing roots have been shown to take up more P (Powell 1977).

In a literature review, Deru et al. (2010) identified a number of environmental, agronomic and genetic factors influencing grass root growth and morphology. Rooting depth and root density are strongly influenced by soil physical characteristics such as soil type and bulk density (Houlbrooke et al. 1997; Steingrobe et al. 2000), as well as by soil chemical and biological factors (Davidson 1969; Powell 1977; Hoogerkamp et al. 1983; He et al. 1999; Scheu 2003; Kutschera et al. 2009) and climatic conditions (Evans 1971; Gales 1979; Troughton 1980). Furthermore, rooting of grasses is influenced by agricultural management factors: most importantly, fertilization (Fairley 1985; Ennik et al. 1980; Forde and Lorenzo 2001), mowing and grazing strategies (Evans 1971, 1972; Ennik and Baan Hofman 1983; Deinum 1985; Dawson et al. 2003), and grassland age (Van Eekeren et al. 2008). Finally, rooting is influenced by genetic characteristics: several studies have reported genetic differences in root biomass between various grass species (Van Eekeren et al. 2010; Cougnon et al. 2013) and varieties of perennial ryegrass (Bonos et al. 2004; Crush et al. 2007), and in root weight of wild versus bred perennial ryegrasses (Crush et al. 2009). These latter experiments (Bonos et al. 2004; Crush et al. 2007; Crush et al. 2009) were conducted in tubes under controlled glasshouse conditions, and covered only a short time period.

The aim of the present study was to investigate the genetic variation in root morphology of bred forage varieties of Lolium perenne under field conditions. To this end, we measured root mass and root density in two long-term field experiments that are part of the 'Value for Cultivation and Use (VCU)' testing programme for the Dutch Variety List. To investigate whether root morphological characteristics are linked to aboveground and genetic characteristics, we tested a selection of varieties with contrasting combinations of characteristics such as productivity, ploidy, earliness and grass cover. Measurement of root uptake activity was not part of the experiment.

\section{Materials and methods}

\section{Experiment I}

For this experiment we selected eight L. perenne (Lp) varieties from a field trial that is part of the VCU testing programme for the Dutch Variety List. This trial was sown in 2005 with $50 \mathrm{Lp}$ varieties in four replicate plots. The eight selected varieties combined an orthogonal distribution of three characteristics with two levels each: 'Ploidy' (diploid versus tetraploid), 'Productivity' (high versus low; based on the yield index for all 50 varieties across the years 2006, 2007 and 2008) and 'Earliness' (early versus late; based on the yield index of the first cut for all 50 varieties across the years 2006, 2007 and 2008) (Table 1).

The experimental field was located on a sandy soil (Plaggeptic Haploquod [USDA] with an A-horizon of $80-100 \mathrm{~cm})$ in the province of Overijssel, The Netherlands $\left(52.50^{\circ} \mathrm{N}, 6.40^{\circ} \mathrm{E}\right)$. During the VCU testing period (2006-2008) and the following years (2009-2010) the experiment was managed according to a cutting regime with five cuts per year. The total $\mathrm{N}$ applied with slurry manure and artificial fertilizer was $350 \mathrm{~kg} \mathrm{~N} \mathrm{ha}^{-1}$ year $^{-1}$. Other nutrients were added according to the official Dutch fertilization recommendations (www.bemestingsadvies.nl). Grass yield of each cut was measured (2006-2008) using a 'Haldrup' small-plot harvester (J. Haldrup a/s, 
Table 1 Characteristics of Lolium perenne varieties in Experiments I and II

\begin{tabular}{|c|c|c|c|c|}
\hline \multirow[t]{2}{*}{ Variety nr. } & \multirow[t]{2}{*}{ Code } & \multicolumn{3}{|c|}{ Variety characteristic } \\
\hline & & Ploidy & $\begin{array}{l}\text { Productivity } \\
\text { category } \\
\text { (yield index) }\end{array}$ & $\begin{array}{l}\text { Earliness } \\
\text { category } \\
\text { (yield index } 1^{\text {st }} \text { cut) }\end{array}$ \\
\hline \multicolumn{5}{|c|}{ Experiment I } \\
\hline 1 & $2 \mathrm{HE}$ & Diploid & High $(102 \%)$ & Early (111\%) \\
\hline 2 & 2HLa & Diploid & High $(100 \%)$ & Late $(84 \%)$ \\
\hline 3 & 2LE & Diploid & Low $(97 \%)$ & Early $(96 \%)$ \\
\hline 4 & $2 \mathrm{LLa}$ & Diploid & Low $(93 \%)$ & Late $(89 \%)$ \\
\hline 5 & $4 \mathrm{HE}$ & Tetraploid & High $(103 \%)$ & Early (123\%) \\
\hline 6 & 4HLa & Tetraploid & High (101\%) & Late $(91 \%)$ \\
\hline 7 & $4 \mathrm{LE}$ & Tetraploid & Low $(99 \%)$ & Early (104 \%) \\
\hline 8 & 4LLa & Tetraploid & Low $(99 \%)$ & Late $(82 \%)$ \\
\hline \multicolumn{5}{|c|}{ Experiment II } \\
\hline 9 & $2 \mathrm{HH}$ & Diploid & High (105\%) & High (84 \%) \\
\hline 10 & $2 \mathrm{HL}$ & Diploid & High $(104 \%)$ & Low $(78 \%)$ \\
\hline 11 & $2 \mathrm{LH}$ & Diploid & Low $(97 \%)$ & High $(85 \%)$ \\
\hline 12 & $2 \mathrm{LL}$ & Diploid & Low $(96 \%)$ & Low $(78 \%)$ \\
\hline 13 & $4 \mathrm{HH}$ & Tetraploid & High $(105 \%)$ & High $(79 \%)$ \\
\hline 14 & $4 \mathrm{HL}$ & Tetraploid & High (104\%) & Low $(74 \%)$ \\
\hline 15 & $4 \mathrm{LH}$ & Tetraploid & Low $(94 \%)$ & High $(81 \%)$ \\
\hline 16 & 4LL & Tetraploid & Low $(93 \%)$ & Low $(74 \%)$ \\
\hline
\end{tabular}

Løgstør, Denmark). Grass was weighed and sampled for determination of dry matter content.

In October 2010, 5 years after the establishment of the experiment, three soil cores $(8.5 \mathrm{~cm}$ diameter) were taken at three depths $(0-8,8-16$ and $16-24 \mathrm{~cm})$ per plot with a root auger (Eijkelkamp, Giesbeek, The Netherlands) to determine root dry matter (RDM) and root length density (RLD). These three soil cores were pooled to one sample for each depth, per plot. This way, four replicate plots were sampled for each variety. The fresh samples were washed carefully through a sieve (mesh size $2 \mathrm{~mm}$ ) to remove soil; other non-root particles were hand-picked from the samples. Root length per diameter class was measured with the whole root sample, or a sub-sample when the sample was too large, by image analysis using WinRHIZO-software (Bouma et al. 2000) (scan resolution 400 dpi; filter of particles smaller than $0.2 \mathrm{~cm}^{2}$ and with a length/width ratio lower than 6; twenty diameter classes: from 0.00 to $0,95 \mathrm{~mm}$ in steps of $0.05 \mathrm{~mm}$ and $>0.95 \mathrm{~mm}$ ). From these data, RLD (root length per soil volume, $\mathrm{cm} \mathrm{cm}^{-3}$ ) and mean root diameter $(\mathrm{mm})$ were calculated. RDM $\left(\mathrm{kg} \mathrm{ha}^{-1}\right.$ ) was determined after drying the samples, first $24 \mathrm{~h}$ at $70{ }^{\circ} \mathrm{C}$ and then $1 \mathrm{~h}$ at $105{ }^{\circ} \mathrm{C}$.
Using the most recent above-ground grass yield data (2008), the grass yield to root ratio was calculated as the grass dry matter (DM) yield $\left(\mathrm{kg} \mathrm{DM} \mathrm{ha}^{-1}\right)$ in 2008 divided by $\mathrm{RDM}_{0-24 \mathrm{~cm}}\left(\mathrm{~kg} \mathrm{ha}^{-1}\right)$ in 2010 . Grass yield to root ratio is not including stubble yields.

\section{Experiment II}

The second experiment was conducted at a different field site, located on a sandy soil (Plaggeptic Haploquod [USDA]) in the same province as Experiment I $\left(52.31 \mathrm{~N}, 6.22^{\circ} \mathrm{E}\right)$, but managed as a cutting/grazing pasture (two cuttings/four grazings per year). This trial contains $80 \mathrm{Lp}$ varieties sown in 2009 in four replicate plots, and is also part of the VCU testing programme for the Dutch Variety List. The $\mathrm{N}$ applied with slurry manure and artificial fertilizer was $260 \mathrm{~kg} \mathrm{~N}^{-1}$ year $^{-1}$. Other nutrients were added according to the official Dutch fertilization recommendations (www. bemestingsadvies.nl). Grass yield was measured (2010-2012) as in Experiment I, but in such a way that the effect of grazing on production was included in the measurements. In short, we divided plots into five equal sub-plots and carried out subsequent yield 
measurements before the whole field was mown or grazed, every time in a following sub-plot. The sixth measurement was done in the sub-plot that had been used for the first measurement.

As in Experiment I, we selected eight Lp varieties for Experiment II, combining an orthogonal distribution of three characteristics with two levels each: 'Ploidy' (diploid versus tetraploid), 'Productivity' (high versus low; based on the yield index for all 80 varieties in the year 2012), and 'Grass Cover' (high versus low; measured by visual estimation in the year 2012) (Table 1). The varieties selected in Experiment II were different from the varieties tested in Experiment I.

Four years after sowing, in September 2013, the selected varieties were sampled for RDM using the same method as in Experiment I. Grass yield to root ratio was calculated using the grass yield of 2012 and the $\mathrm{RDM}_{0-24 \mathrm{~cm}}$ of 2013 and without taking account of stubble yields.

\section{Statistical analysis}

Both experiments were laid out as randomized block designs with four blocks. Software package Genstat 13.3 (VSN International Ltd. 2010) was used for statistical analyses. For each experiment, we tested homogeneity of variances with Bralett's test. Data were further analyzed by one-way ANOVA for variety effect and three-way ANOVA for the factors 'Ploidy', 'Productivity' and 'Earliness' and their interactions (Experiment I) and 'Ploidy', 'Productivity' and 'Grass Cover' and their interactions (Experiment II). We assumed a significance level of $5 \%$.

Due to the time difference between grass yield measurements and root sampling, we checked for the effect on the results when calculating grass yield to shoot ratio with grass yield from different years. The different ANOVA outputs gave no shifts in significance of factor effects on the grass yield to shoot ratio. This is confirmed by the lower within- and betweenyear variation in grass yield compared to the variation in RDM: the standard deviation of grass yield ranged form 4 to $8 \%$ (standard deviation expressed as percentage of the mean per year and experiment), the average of the between-year standard deviations was $8 \%$ of the grass yield for both experiments, whereas for RDM, the standard deviation was 23 and $24 \%$ of the mean total RDM in Experiment I and II, respectively.

\section{Results}

\section{RDM and RLD, Experiment I}

We found a significant effect of variety on RDM in all but the 16-24 cm soil layers (Fig. 1; Table 2). For the eight varieties investigated, total RDM in the $0-24 \mathrm{~cm}$ soil layer was most strongly influenced by ploidy (Table 2): diploid varieties had higher RDM than tetraploid varieties $(p=0.002)$. We found a significant interaction between ploidy and earliness ( $0-8$ and 0-24 cm), showing that late tetraploid varieties had higher RDM than early tetraploid varieties (though still lower than diploid varieties) $(p=0.044)$. Furthermore, the significant interaction between earliness and productivity category showed that early 'High productivity' varieties had lower RDM than late 'High productivity' varieties and early 'Low productivity' varieties $(p=0.008)$. The same patterns were observed for the top $0-8 \mathrm{~cm}$ soil layer. In the 8-16 cm layer, only ploidy influenced RDM significantly $(p=0.001$; with higher RDM in diploid varieties); and in the 16-24 cm layer, only earliness $(p=0.010$; with a higher RDM in early than in late varieties). RDM was not affected by aboveground productivity category.

The proportion of $\mathrm{RDM}_{8-24 \mathrm{~cm}}$ to total RDM was highest in the late diploid varieties and lowest in the early diploid and late tetraploid varieties. Also, within the varieties in the low productivity category, $\mathrm{RDM}_{8-24 \mathrm{~cm}}$ to total RDM ratio was highest in the late varieties and lowest in the early varieties (significant Ploidy * Earliness and Productivity * Earliness interactions; data not shown).

RDM and RLD were strongly correlated; the slope of the regression line was similar between the $0-8$ and 8-24 cm soil layers (Fig. 2). Consequently, we found the same significant factor effects for RLD as for RDM. However, ploidy effects were slightly stronger on RLD than on RDM ( $p<0.001$ for $0-24 \mathrm{~cm}$ ), with a significant effect in all three soil layers.

\section{RDM, Experiment II}

In Experiment II, we found an almost significant variety effect on RDM in the $0-24 \mathrm{~cm}$ soil layer $(p=0.053)$, and a significant variety effect in the $8-16 \mathrm{~cm}$ layer ( $p=0.008$; Table 2$)$. RDM in the $0-8$ and $0-24 \mathrm{~cm}$ layers was significantly influenced by 
Fig. 1 Cumulated root mass (kg RDM ha ${ }^{-1}$ ) of 16 Lolium perenne varieties (Experiments I and II) with different genetic and aboveground characteristics (for abbreviations, see Table 1). Error bars represent + and - the standard error of RDM across the $0-24 \mathrm{~cm}$ soil layer

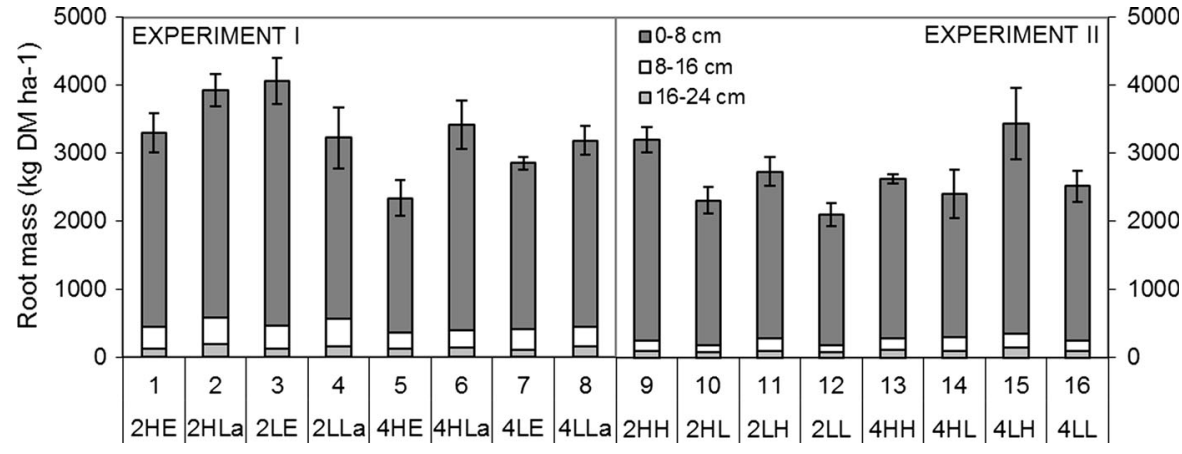

5,000-8,000 $\mathrm{kg} \mathrm{ha}^{-1}$ under different grazing systems. Although not statistically comparable, the grand mean RDM in the 0-24 cm soil layer in Experiment II was lower than in Experiment I (Table 2). In Experiment I, total nitrogen applied with slurry manure and artificial fertilizer was higher than in Experiment II (350 versus $260 \mathrm{~kg} \mathrm{~N} \mathrm{ha}^{-1}$ year $^{-1}$, respectively). Ennik et al. (1980) and Ennik and Baan Hofman (1983) found increased root mass with decreased $\mathrm{N}$ fertilizer rates in Lp varieties. However, in Experiment II, an estimated $80 \mathrm{~kg} \mathrm{ha}^{-1}$ year $^{-1}$ extra $\mathrm{N}$ input from dung and urine during grazing should be added to the total $\mathrm{N}$ input, making the difference between the experiments smaller. Besides differences in abiotic conditions and sampling year between the experiments, the more intensive cutting/grazing regime in Experiment II may have contributed to reduced RDM. Ennik and Baan Hofman (1983) measured a lower RDM with higher harvesting frequencies.

In Experiment I, the tested Lp varieties showed significant differences in RDM in the 0-24, 0-8 and $8-16 \mathrm{~cm}$ soil layers. These results, obtained under field conditions, confirm differences measured by Bonos et al. (2004) and Crush et al. (2009) in test tubes in greenhouses. However, in Experiment II a significant variety effect on RDM was found only in the $8-16 \mathrm{~cm}$ soil layer, with a close to significant effect $(p=0.053)$ for total RDM in the $0-24 \mathrm{~cm}$ layer. Possibly, the selected varieties in Experiment II had less genetic variation in RDM, or expressed this variation to a lesser extent under the phenotypic conditions in Experiment II than in Experiment I. In addition to soil and micro-climatic differences between the field sites, an important difference between Experiment I and II was the management of the sward: only cutting in the former, versus a more intensive cutting/grazing regime in the latter, which
RDM measured in the $0-24 \mathrm{~cm}$ soil layer for the different Lolium perenne varieties in Experiment I and II ranged from 2,096 to $4,053 \mathrm{~kg} \mathrm{ha}^{-1}$ (varieties 12 and 3 , respectively). This was lower than reported by Deinum (1985), who measured root biomass of 
Table 2 Root mass ( $\mathrm{kg} \mathrm{RDM} \mathrm{ha}^{-1}$ ) per soil layer in Experiments I and II: grand mean, variety effects, means per characteristic level and means of the significant interactions between characteristics. s.e.: standard error of the mean

\begin{tabular}{|c|c|c|c|c|c|c|c|c|c|}
\hline \multicolumn{5}{|l|}{ Experiment I } & \multicolumn{5}{|c|}{ Experiment II } \\
\hline & \multicolumn{4}{|c|}{ Soil layer $(\mathrm{cm})$} & & \multicolumn{4}{|c|}{ Soil layer $(\mathrm{cm})$} \\
\hline & Total $0-24$ & $0-8$ & $8-16$ & $16-24$ & & Total 0-24 & $0-8$ & $8-16$ & $16-24$ \\
\hline Grand mean & 3,286 & 2,824 & 318 & 144 & & 2,663 & 2,403 & 158 & 102 \\
\hline s.e. $(n=32)$ & 131 & 119 & 16 & 9 & & 114 & 110 & 10 & 6 \\
\hline Variety effect & 0.004 & 0.004 & 0.049 & 0.299 & & 0.053 & 0.094 & 0.008 & 0.169 \\
\hline \multicolumn{10}{|l|}{ Ploidy } \\
\hline 2 (diploid) & 3,624 & 3,109 & 365 & 152 & & 2,583 & 2,359 & 138 & 87 \\
\hline 4 (tetraploid) & 2,949 & 2,540 & 271 & 135 & & 2,742 & 2,448 & 178 & 117 \\
\hline s.e. 2 & 178 & 166 & 19 & 15 & & 138 & 130 & 14 & 7 \\
\hline s.e. 4 & 153 & 143 & 19 & 11 & & 185 & 180 & 12 & 10 \\
\hline$P$ value & 0.002 & 0.003 & 0.001 & 0.364 & & 0.445 & 0.666 & 0.010 & 0.021 \\
\hline \multicolumn{10}{|l|}{ Productivity } \\
\hline High & 3,242 & 2,792 & 303 & 147 & & 2,631 & 2,378 & 155 & 98 \\
\hline Low & 3,330 & 2,856 & 333 & 140 & & 2,694 & 2,428 & 160 & 105 \\
\hline s.e. $\mathrm{H}$ & 197 & 172 & 19 & 15 & & 135 & 131 & 14 & 8 \\
\hline s.e. L & 178 & 170 & 25 & 11 & & 189 & 181 & 14 & 10 \\
\hline$P$ value & 0.645 & 0.712 & 0.250 & 0.720 & & 0.761 & 0.806 & 0.736 & 0.543 \\
\hline Earliness & & & & & Grass co & & & & \\
\hline Early & 3,437 & 2,939 & 332 & 167 & High & 2,996 & 2,706 & 176 & 114 \\
\hline Late & 3,135 & 2,710 & 304 & 120 & Low & 2,329 & 2,100 & 139 & 90 \\
\hline s.e. E & 272 & 246 & 26 & 14 & s.e. $\mathrm{H}$ & 238 & 224 & 17 & 12 \\
\hline s.e. L & 263 & 227 & 31 & 16 & s.e. L & 181 & 167 & 15 & 9 \\
\hline$P$ value & 0.120 & 0.195 & 0.286 & 0.019 & & 0.004 & 0.007 & 0.016 & 0.057 \\
\hline \multicolumn{5}{|c|}{ Ploidy $\times$ earliness } & \multicolumn{5}{|c|}{ Productivity $\times$ grass cover } \\
\hline $2 \mathrm{E}$ & $3,674 \mathrm{~b}$ & $3,215 \mathrm{~b}$ & & & $\mathrm{HH}$ & & & $157 \mathrm{ab}$ & \\
\hline $2 \mathrm{~L}$ & $3,577 \mathrm{~b}$ & $3,003 \mathrm{~b}$ & & & $\mathrm{HL}$ & & & $153 \mathrm{ab}$ & \\
\hline $4 \mathrm{E}$ & $2,595 \mathrm{a}$ & $2,206 \mathrm{a}$ & & & LH & & & $195 \mathrm{~b}$ & \\
\hline $4 \mathrm{~L}$ & $3,298 \mathrm{~b}$ & $2,874 \mathrm{~b}$ & & & LL & & & $125 \mathrm{a}$ & \\
\hline s.e. $2 \mathrm{E}$ & 251 & 246 & & & s.e. $\mathrm{HH}$ & & & 18 & \\
\hline s.e. $2 \mathrm{~L}$ & 270 & 232 & & & s.e. HL & & & 24 & \\
\hline s.e. $4 \mathrm{E}$ & 161 & 139 & & & s.e. LH & & & 18 & \\
\hline s.e. $4 \mathrm{~L}$ & 197 & 190 & & & s.e. LL & & & 11 & \\
\hline$P$ value & 0.044 & 0.018 & & & & & & 0.028 & \\
\hline \multicolumn{10}{|c|}{ Productivity $\times$ earliness } \\
\hline $\mathrm{HE}$ & $2,816 \mathrm{a}$ & $2,405 \mathrm{a}$ & & & & & & & \\
\hline HL & $3,668 \mathrm{~b}$ & $3,179 \mathrm{~b}$ & & & & & & & \\
\hline LE & $3,453 \mathrm{~b}$ & $3,015 \mathrm{~b}$ & & & & & & & \\
\hline LL & $3,206 \mathrm{ab}$ & $2,698 \mathrm{ab}$ & & & & & & & \\
\hline s.e. HE & 255 & 229 & & & & & & & \\
\hline s.e. HL & 221 & 179 & & & & & & & \\
\hline s.e. LE & 279 & 271 & & & & & & & \\
\hline s.e. LL & 231 & 206 & & & & & & & \\
\hline
\end{tabular}


Table 2 continued

\begin{tabular}{|c|c|c|c|c|c|c|c|c|}
\hline \multicolumn{5}{|c|}{ Experiment I } & \multicolumn{4}{|l|}{ Experiment II } \\
\hline & \multicolumn{4}{|c|}{ Soil layer (cm) } & \multicolumn{4}{|c|}{ Soil layer $(\mathrm{cm})$} \\
\hline & Total $0-24$ & $0-8$ & $8-16$ & $16-24$ & Total $0-24$ & $0-8$ & $8-16$ & $16-24$ \\
\hline value & 0.008 & 0.00 & & & & & & \\
\hline
\end{tabular}

$P$ values in italic; bold and italic $\boldsymbol{P}$ values are significant. In factor interactions, numbers within one column followed by different letters are significantly different

Fig. 2 Relation between RDM and RLD in Experiment $\mathrm{I}$ in soil layers $0-8$ and $8-24 \mathrm{~cm}$. Note the scale differences between the two graphs
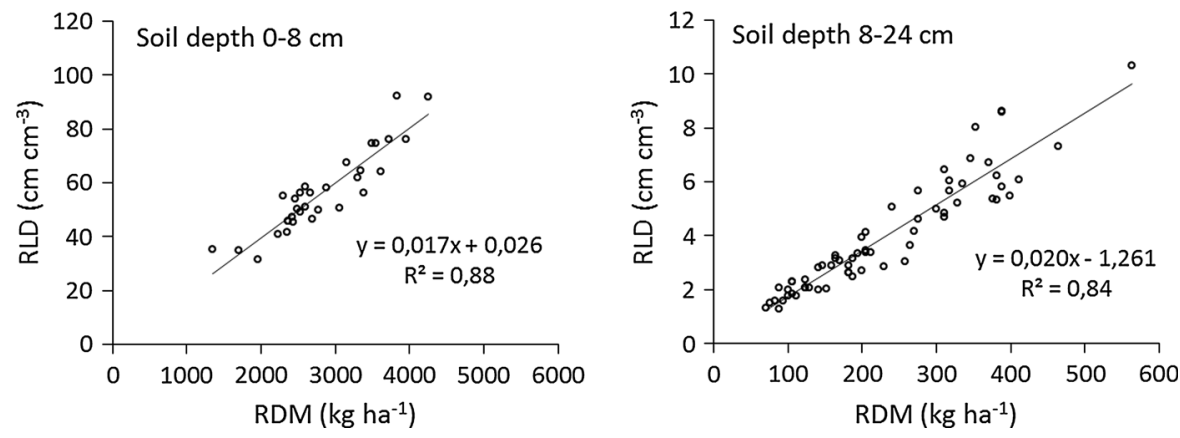

could have affected the expression of RDM of the different varieties. Another possible contribution to the smaller effects in Experiment II is the probably higher heterogeneity within the plots due to dung and urine patches, resulting in a higher variation in sampled material. This is confirmed by the higher standard deviation of the standard errors of the eight Lp varieties in Experiment II compared to the standard deviation of the standard errors of the varieties in Experiment I (data not shown).

In both experiments, RDM was not significantly influenced by productivity category. This implies that high-yielding varieties could be combined with a high RDM. This is in line with the results of Crush et al. (2007, 2009), who stated that increased belowground production (root dry weight) need not compromise aboveground productivity (shoot dry weight). The lack of effect of productivity category on RDM does not exclude the possibility that, under stress conditions (e.g. water or nutrient limitation), a better developed root system could provide a more stable above-ground production. Here, we have to mention that our study was limited to root morphology and no account was taken of genetic differences in root activity, seasonal variation in rooting or root turnover. To better understand the contribution of rooting to variety performance or soil quality, these aspects need to be researched, including a broader range of soil conditions and grassland management factors.

In Experiment I, the diploid varieties had a significantly higher RDM in the $0-24,0-8$ and $8-16 \mathrm{~cm}$ soil layers than the tetraploid varieties. In other research on grass varieties and RDM, no comparisons are made in relation to ploidy. Since Deinum (1985) related RDM to the number of tillers, our hypothesis was that the lower RDM of tetraploid varieties could be related to the generally more open growth habit and lower grass cover of these varieties. However, in Experiment I the variation in grass cover between varieties was low (average grass cover of $83 \%$ with a standard deviation of $1.2 \%$ ). Therefore, for Experiment II we selected varieties based on two levels of grass cover: here, the mean grass cover was $79 \%$, with a larger standard deviation (4.3\%). In this experiment, grass cover had a significant effect on RDM in the $0-24,0-8$ and $8-16 \mathrm{~cm}$ soil layers, but ploidy had a significant effect only in the 8-16 and 16-24 cm soil layers. In these layers the tetraploid varieties had a higher RDM than diploid varieties, reversing the pattern observed in Experiment I.

The proportion of RDM in the top $8 \mathrm{~cm}$ was 86 and $90 \%$ in Experiments I and II, respectively, and in general, treatment effects were larger in the top layers. In comparing RDM of $L$. perenne and Festuca 
Table 3 Mean grass yield to root ratio $\left(\mathrm{kg} \mathrm{kg}^{-1}\right)$ in Experiments I and II and means of the significant interaction between 'Productivity' and 'Earliness' in Experiment I. s.e.: standard error of the mean

\begin{tabular}{|c|c|c|c|c|c|}
\hline \multicolumn{3}{|l|}{ Experiment I } & \multicolumn{3}{|c|}{ Experiment II } \\
\hline & $\begin{array}{l}\text { Grass } \\
\text { yield to } \\
\text { root } \\
\text { ratio }\end{array}$ & s.e. & & $\begin{array}{l}\text { Grass } \\
\text { yield to } \\
\text { root } \\
\text { ratio }\end{array}$ & s.e. \\
\hline Grand mean & 3.93 & 0.20 & & 4.68 & 0.20 \\
\hline $\begin{array}{r}\text { Variety } \\
\text { effect }\end{array}$ & 0.006 & & & 0.059 & \\
\hline \multicolumn{6}{|l|}{ Ploidy } \\
\hline Diploid & 3.44 & 0.21 & & 4.80 & 0.27 \\
\hline Tetraploid & 4.42 & 0.30 & & 4.57 & 0.30 \\
\hline$P$ value & 0.002 & & & 0.533 & \\
\hline \multicolumn{6}{|l|}{ Productivity } \\
\hline High & 4.11 & 0.35 & & 5.00 & 0.28 \\
\hline Low & 3.75 & 0.21 & & 4.37 & 0.27 \\
\hline$P$ value & 0.213 & & & 0.097 & \\
\hline Earliness & & & $\begin{array}{l}\text { Grass } \\
\text { cover }\end{array}$ & & \\
\hline Early & 3.67 & 0.40 & High & 4.12 & 0.32 \\
\hline Late & 4.19 & 0.31 & Low & 5.25 & 0.42 \\
\hline$P$ value & 0.075 & & $P$ value & 0.005 & \\
\hline \multicolumn{6}{|c|}{ Productivity $\times$ earliness } \\
\hline $\mathrm{HE}$ & $4.71 \mathrm{~b}$ & 0.55 & & & \\
\hline HL & $3.50 \mathrm{a}$ & 0.33 & & & \\
\hline LE & $3.66 \mathrm{a}$ & 0.28 & & & \\
\hline LL & $3.84 \mathrm{a}$ & 0.33 & & & \\
\hline$P$ value & 0.020 & & & & \\
\hline
\end{tabular}

$P$ values in italic; bold and italic $\boldsymbol{P}$ values are significant. In factor interaction, numbers followed by the same letter are not significantly different

arundinacea $(\mathrm{Fa})$, Cougnon et al. (2013) found a similar decline with depth for Lp. For Fa, the proportion of deep roots was higher.

The grass yield to root ratios in our field experiments were higher than the shoot to root ratios observed in the greenhouse experiments by Crush et al. (2009) and Moir et al. (2012). This could imply that it is more difficult for grasses to achieve their genetic rooting potential under field conditions. In our experiments, we found that the effects of genetic and aboveground characteristics on grass yield to root ratio were similar to effects on RDM, due to the fact that variation in grass yield between varieties was small.
In summary, we found that under field conditions the root mass of perennial ryegrass differed significantly between varieties. These differences were not linked to grass yield, which indicates that it is possible to select perennial ryegrass varieties that combine high aboveground productivity with high root mass. Considering challenges in the areas of climate change, water availability, water pollution, and soil degradation due to erosion and loss of organic matter, even on dairy farms with grassland (Verloop 2013), varieties with improved root systems could significantly contribute to a more efficient use of nutrients and water, to erosion control, soil improvement and carbon sequestration. The potential for improvement is certainly there, considering that Crush et al. (2006) reported a narrow-sense heritability value of 0.35 for perennial ryegrass, and Bonos et al. (2004) increased root mass in the deeper soil layer of forage type perennial ryegrass in test tubes by $367 \%$ after only two breeding cycles.

Acknowledgments This research was part of the project Bufferboeren, financed by the following Dutch institutions: Agricultural Innovation Bureau (LIB), Dairy Board (PZ), Brabant Water, Water Board Aa en Maas, Rabobank Bernheeze, Foundation for Applied Water Research (STOWA), NCB-fund and Ministry of Infrastructure and Environment (I\&M). We want to thank the Dutch breeders association Plantum for the opportunity to take root samples in the VCU trials.

\section{References}

Abberton MT, Marshall AH, Humphreys MW, Macduff JH, Collins RP, Marley CL (2008) Genetic improvement of forage species to reduce the environmental impact of temperate livestock grazing systems. Adv Agron 98:311-355

Andrews RE, Newman EI (1970) Root intensity and competition for nutrients. Oecol Plant 5:319-334

Atkinson D, Black KE, Dawson A, Dunsiger Z, Watson CA, Wilson SA (2005) Prospects, advantages and limitations of future crop production systems dependent upon the management of soil processes. Ann Appl Biol 146:203-215

Baan Hofman T, Ennik GC (1980) Investigation into plant characters affecting the competitive ability of perennial ryegrass (Lolium perenne L.). Neth J Agric Sci 28:97-100

Bonos SA, Rush D, Hignight K, Meyer WA (2004) Selection for deep root production in tall fescue and perennial Ryegrass. Crop Sci 44:1770-1775

Bouma TJ, Nielsen KL, Koutstaal B (2000) Sample preparation and scanning protocol for computerised analysis of root length and diameter. Plant Soil 218:185-196 
Bowman DC, Devitt DA, Engelke MC, Rufty TW (1998) Root architecture affects nitrate leaching from bentgrass turf. Crop Sci 38:1633-1639

Bronick CJ, Lal R (2005) Soil structure and management: a review. Geoderma 124:3-22

Cougnon M, Deru J, Van Eekeren N, Baert J, Reheul D (2013) Root depth and biomass of tall fescue vs. perennial ryegrass. Grassl Sci Eur 18:285-287

Crush JR, Easton HS and Waller JE (2006) Genetic variation in perennial ryegrass for root profile characteristics. In: Mercer CF (ed) New Zealand Grassland Association Research and Practice Series No. 12. New Zealand Grassland Association, Dunedin, pp 63-65

Crush JR, Easton HS, Waller JE, Hume DE, Faville MJ (2007) Genotypic variation in patterns of root distribution, nitrate interception and response to moisture stress of a perennial ryegrass (Lolium perenne L.) mapping population. Grass Forage Sci 62:265-273

Crush JR, Nichols SN, Easton HS, Ouyang L, Hume DE (2009) Comparison between wild populations and bred perennial ryegrasses for root growth and root/shoot partitioning. $\mathrm{N} \mathrm{Z}$ J Agric Res 52:161-169

Davidson RL (1969) Effects of soil nutrients and moisture on root/shoot ratios in Lolium perenne $\mathrm{L}$ and Trifolium repens L. Ann Bot 33:571-577

Dawson LA, Thornton B, Pratt SM, Paterson E (2003) Morphological and topological responses of roots to defoliation and nitrogen supply in Lolium perenne and Festuca ovina. New Phytol 161:811-818

Deinum B (1985) Root mass of grass swards in different grazing systems. Neth J Agric Sci 33:377-384

Deru J, Van Eekeren N, De Boer H (2010) Rooting of grassland: a literature review on nutrient uptake in relation to rooting depth and density, and on potential measures to stimulate deep and dense rooting of grass (in Dutch, English summary). Louis Bolk Institute, Driebergen-Rijsenburg, p 63

Dunbabin V, Diggle A, Rengel Z (2003) Is there an optimal root architecture for nitrate capture in leaching environments? Plant Cell Environ 26:835-844

Ennik GC, Baan Hofman T (1983) Variation in the root mass of ryegrass types and its ecological consequences. Neth $\mathrm{J}$ Agric Sci 31:325-334

Ennik GC, Gillet M, Sibma L (1980) Effect of high nitrogen supply on sward deterioration and root mass. In: Prins WH, Arnol GH (eds) The role of nitrogen in intensive grassland production. Pudoc, Wageningen, pp 67-76

Evans PS (1971) Root growth of Lolium perenne L. 2. Effects of defoliation and shading. $\mathrm{N}$ Z J Agric Res 14:552-562

Evans PS (1972) Root growth of Lolium perenne L. 3. Investigation of mechanism of defoliation-induced suppression of elongation. N Z J Agric Res 15:347-355

Fairley RI (1985) Grass root production in restored soil following opencast mining. In: Fitter AH, Atkinson D, Read DJ, Usher MB (1985) Ecological interactions in soil. British Ecological Society, London, special publication, vol 4, pp 81-85

Forde B, Lorenzo H (2001) The nutritional control of root development. Plant Soil 232:51-68
Gales K (1979) Effects of water supply on partitioning of dry matter between roots and shoots in Lolium perenne. $\mathrm{J}$ Appl Ecol 16:863-877

Garwood EA, Sinclair J (1979) Water-use and root distribution of grass species. J Sci Food Agric 29:834

He ZL, Baligar VC, Martens DC, Ritchey KD, Elrashidi MA (1999) Relationship of ryegrass growth to extractable phosphorus in acidic soil amended with phosphate rock, coal combustion by-products, limestone and cellulose. Commun Soil Sci Plant Anal 30(3\&4):457-470

Hodge A, Robinson D, Griffiths BS, Fitter AH (1999) Why plants bother: root proliferation results in increased nitrogen capture from an organic patch when two grasses compete. Plant Cell Environ 22:811-820

Hoogerkamp M, Rogaar H, Eysakkers HJP (1983) Effects of earthworms on grassland on recently reclaimed polder soils in the Netherlands. In: Satchell JE (ed) Earthworm ecology: from Darwin to vermiculture. Chapman and Hall, London, pp 85-105

Houlbrooke DJ, Thom ER, Chapman R, McLay CDA (1997) A study of the effects of soil bulk density on root and shoot growth of different ryegrass lines. $\mathrm{N}$ Z J Agric Res 40:429-435

Jackson RB, Canadell J, Ehleringer JR, Mooney HA, Sala OE, Schulze ED (1996) A global analysis of root distribution for terrestrial biomes. Oecologia 108:389-411

Kutschera L, Lichtenegger E, Sobotik M (2009) Wurzelatlas der Kulturpflanzen gemässiger Gebiete mit Arten des Feldgemüsebaues. 7. Band. Frankfurt am Main, DLG-Verlag

Lynch JP (2007) Roots of the Second Green Revolution. Aust J Bot 55:493-512

Moir JL, Edwards GR, Berry LN (2012) Nitrogen uptake and leaching loss of thirteen temperate grass species under high $\mathrm{N}$ loading. Grass Forage Sci 68:313-325

Powell CL (1977) Effect of phosphate fertilizer and plant density on phosphate inflow into ryegrass roots in soil. Plant Soil 47:383-393

Robinson D, Linehan DJ, Caul S (1991) What limits nitrate uptake from soil? Plant Cell Environ 14:77-85

Scheu S (2003) Effects of earthworms on plant growth: patterns and perspectives. Pedobiologia 47:846-856

Snow VO, White TA (2013) Process-based modelling to understand which ryegrass characteristics can increase production and decrease leaching in grazed grass-legume pastures. Crop Pasture Sci 64:265-284

Sprangers JTCM (1999) Vegetation dynamics and erosion resistance of sea dyke grassland. $\mathrm{PhD}$ thesis, Wageningen Agricultural University, Wageningen

Steingrobe B, Schmid H, Claassen N (2000) The use of the ingrowth core method for measuring root production of arable crops-influence of soil conditions inside the ingrowth core on root growth. J Plant Nutr Soil Sci 163:617-622

Troughton A (1980) Production of root axes and leaf elongation in perennial ryegrass in relation to dryness of the upper soil layer. J Agric Sci 95:533-538

Van Eekeren N, Bommelé L, Bloem J, Schouten AJ, Rutgers M, De Goede R, Reheul D, Brussaard L (2008) Soil Biological quality after 36 years of ley-arable cropping, permanent 
grassland and permanent arable cropping. Appl Soil Ecol 40:432-446

Van Eekeren N, Bos M, De Wit J, Keidel H, Bloem J (2010)

Effect of different grass species mixtures on soil quality in relation to root biomass and grass yield. Appl Soil Ecol 45:275-283
Verloop K (2013) Limits of effective nutrient management in dairy farming: analyses of experimental farm De Marke. $\mathrm{PhD}$ thesis, Wageningen University, Wageningen

White TA, Snow VO (2012) A modelling analysis to identify plant traits for enhanced water-use efficiency of pasture. Crop Pasture Sci 63:63-76 